\title{
Mechanical Properties and Free Formaldehyde Content of Particleboards Produced using Ammonium Sulphate- Based Hardener Partially Replaced with Tartaric Acid
}

\section{Mehanička svojstva i sadržaj slobodnog formaldehida ploča iverica izrađenih primjenom katalizatora na bazi amonijeva sulfata djelomično zamijenjenoga vinskom kiselinom}

Original scientific paper • Izvorni znanstveni rad

Received-prispjelo: 24. 10. 2019.

Accepted-prihvaćeno: 15. 7. 2020.

UDK: $630 * 863.21$

https://doi.org/10.5552/drvind.2020.1950

(C) 2020 by the author(s). Licensee Faculty of Forestry, University of Zagreb. This article is an open access article distributed under the terms and conditions of the Creative Commons Attribution (CC BY 4.0) license.

\begin{abstract}
The use of resins, whose curing reaction takes place by high temperature and hardener addition, is inevitably involved in particleboard manufacturing process. In addition to commercial hardeners, such as ammonium sulphate, with the aim of optimizing the production process and reducing the production costs, a certain percentage of hardener can, among other things, be replaced with price affordable bio-based materials. Tartaric acid, that is its salts (tartrates), which are commercially produced for the needs of wine and food industries, are a part of the aforementioned group of products. Since tartaric acid is a relatively inexpensive, readily available, weak diprotic and aldaric acid, the question arises whether it can be used as a component of the hardener system for curing urea-formaldehyde resins that are commercially used in particleboard production. For that reason, in this paper, the influence of partial replacement of ammonium sulphate hardener with tartaric acid on the mechanical properties (bending strength, modulus of elasticity and internal bond) and free formaldehyde content of experimentally produced particleboards was examined. Boards thickness, density and moisture content were also determined. The test results suggest that tartaric acid has a beneficial effect on the above particleboard properties, but they also indicate that the extent of that effect is strongly dependent on panel press time.
\end{abstract}

Key words: particleboards; hardener; tartaric acid; mechanical properties; free formaldehyde content

SAŽETAK • Proces proizvodnje ploča iverica neminovno podrazumijeva upotrebu smola čija se reakcija otvrdnjavanja ostvaruje uz pomoć povišene temperature i katalizatora. Uz komercijalne katalizatore poput amonijeva

\footnotetext{
${ }^{1}$ Authors are assistant professor, professor, associate professor and associate professor at University of Zagreb, Faculty of Forestry, Zagreb, Croatia.

2 Author is PhD student employed at "Ruđer Bošković" Technical and Industrial High School, Sinj, Croatia.
} 
sulfata, radi optimizacije procesa i racionalizacije troškova proizvodnje ploča, katalizatore je u određenom postotku moguće zamijeniti, među ostalim, i cijenom prihvatljivim proizvodima na biobazi. U navedenu se skupinu proizvoda svrstava $i$ vinska kiselina, točnije njezine soli (tartarati), komercijalno proizvedene za potrebe vinske $i$ prehrambene industrije. S obzirom na to da je vinska kiselina relativno jeftina, lako dostupna, slaba diprotonska, aldarna kiselina, postavlja se pitanje potencijala njezine primjene u sustavima katalizatora za otvrdnjavanje ureaformaldehidne smole koja se upotrebljava u proizvodnji ploča iverica. Upravo je zato u ovom radu ispitano kako se zamjena dijela amonijeva sulfata tartaratnom kiselinom odražava na mehanička svojstva (savojnu čvrstoću, modul elastičnosti, vlačnu čvrstoću) i na koncentraciju slobodnog formaldehida eksperimentalno proizvedenih ploča iverica. Usto, u eksperimentu su određene debljina i gustoća ploča te sadržaj vode u njima. Rezultati ispitivanja upućuju na to da dodatak vinske kiseline povoljno utječe na navedena svojstva ploča, ali i na činjenicu kako taj učinak iznimno ovisi o vremenu prešanja ploča.

Ključne riječi: ploče iverice; katalizator; vinska kiselina; mehanička svojstva; koncentracija slobodnog formaldehida

\section{INTRODUCTION}

\section{UVOD}

The urea-formaldehyde (UF) resin is the predominant resin in today's modern particleboard production. This is due to its low price, water solubility, fire resistance, good thermal conductivity, absence of colour of cured resin and its easy adaptation to different curing conditions (Pizzi, 2003). Commonly, UF resins are cured at elevated temperatures using acidic hardeners (catalyst), such as ammonium sulphate $\left(\left(\mathrm{NH}_{4}\right)_{2} \mathrm{SO}_{4}\right)$. As resin curing depends on the type of hardener, its addition, $\mathrm{pH}$ value and solid content (Uner and Olgun, 2017; Xing et al., 2007), the use of various hardeners, other than the above mentioned, is also possible. Such hardeners include ammonium chloride (Xing et al., 2007), sodium chloride, sodium chlorite and borax (Uner and Olgun, 2017), ammonium citrate and zinc nitrate (Park et al., 2003), aluminium chloride and aluminium sulphate (Aizat et al., 2019), ammonium formate for melamine-urea-formaldehyde resins (Čuk et al., 2011) and ammonium persulfate and ferrum (III) chloride if UF resins are used for plywood bonding (Bekhta et al., 2016).

As for the natural acids, attempts were made to use citric and oxalic acids as hardeners in crude state after the wood particles were blended with adhesive mixtures. The use of such hardeners for curing commercial UF resins resulted in a slight rise in the free formaldehyde content (to the upper limit of the E1 emission class). However, if oxalic acid was used neat or in combination with ammonium sulphate for curing low formaldehyde to urea molar ratio UF resin, produced particleboards had high values of internal bond (IB) with free formaldehyde values $\leq 4.5 \mathrm{mg} / 100 \mathrm{~g}$ oven dry board (Costa et $a l ., 2014)$. The use of citric acid-sucrose mixtures as binders for particleboard production was also attempted. The results showed that although citric acid and sucrose mixtures have great potential as binders for particleboards, the final effect of their use is highly dependent on targeted board density and press temperature. Boards pressed at $200{ }^{\circ} \mathrm{C}$ with targeted density of $0.8 \mathrm{~g} / \mathrm{cm}^{3}$ had values of mechanical (bending strength (MOR) and modulus of elasticity (MOR)) and physical properties (water absorption and swelling in thickness) in the range or above those minimum required by the applicable standards (Widyorini et al., 2016; Umemura et al., 2013, 2015). As for the low density, when insulating particleboards were pressed using the same binder mixtures, the MOR and swelling in thickness values increased with increasing the board density, and boards with targeted density of $0.4 \mathrm{~g} / \mathrm{cm}^{3}$ pressed by adding $15 \%$ binder met the standards requirements (Liao et al., 2016).

Given that our earlier work, in which we have examined the neat resin-catalyst systems (Španić et al., 2017), showed that tartaric acid $\left(\mathrm{C}_{4} \mathrm{H}_{6} \mathrm{O}_{6}\right)$ could be successfully used as a part of hardener for UF resin curing, and taking into consideration the above mentioned results of other authors, in this paper the experimental particleboards were produced and their mechanical properties and free formaldehyde content were determined. Boards with nominal thickness of $15 \mathrm{~mm}$ were made using ammonium sulphate hardener, partially replaced with tartaric acid, with pressing temperature set at $175{ }^{\circ} \mathrm{C}$ and pressing time varying from 240 to 300 seconds.

\section{MATERIALS AND METHODS 2. MATERIJALI I METODE}

In this study, four series ( 8 boards in total) of three-layer particleboards sized $45 \times 37 \times 15(\mathrm{~mm})$ were produced using industrial particles of various wood species and commercial urea-formaldehyde resin. Paraffin emulsion was used as hydrophobic agent and ammonium sulphate-based catalyst partially modified with tartaric acid ( $1 \%$ addition) was used as hardener. Face and core particles, urea-formaldehyde resin, industrial grade ammonium sulphate and paraffin emulsion were obtained from Kronospan CRO Ltd. Industrial grade tartaric acid $(\mathrm{L}-(+)$-tartaric acid) for oenological purposes was obtained from Begerow $\mathrm{GmbH} \& \mathrm{Co}$. Deionised water used for catalyst preparation was ASTM type II, and prepared using TKA MicroMed system.

\subsection{Particleboard production}

\subsection{Izrada ploča iverica}

The moisture content for face layer and core layer particles was $7 \%$ and $5 \%$, respectively, as determined gravimetrically. Such particles were used to make 16 $\mathrm{mm}$ thick particleboards with target density of $0.75 \mathrm{~g} /$ 
Table 1 Experimental design for produced particleboards

Tablica 1. Parametri za izradu eksperimentalnih ploča iverica

\begin{tabular}{|c|c|c|c|c|}
\hline $\begin{array}{c}\text { Panel series } \\
\text { Serija ploča }\end{array}$ & $\begin{array}{c}\text { Press temperature } \\
\text { Temperatura prešanja } \\
{ }^{\circ} \mathrm{C}\end{array}$ & $\begin{array}{c}\text { Press pressure } \\
\text { Tlak prešanja } \\
\mathrm{N} / \mathrm{mm}^{2}\end{array}$ & $\begin{array}{c}\text { Pressing time } \\
\text { Vrijeme prešanja } \\
\mathrm{S}\end{array}$ & $\begin{array}{c}\text { Hardener type } \\
\text { Vrsta katalizatora }\end{array}$ \\
\hline A & 175 & 3.2 & 300 & neat $\left(\mathrm{NH}_{4}\right)_{2} \mathrm{SO}_{4}$ \\
\hline B & 175 & 3.2 & 300 & $\left(\mathrm{NH}_{4}\right)_{2} \mathrm{SO}_{4}+\mathrm{C}_{4} \mathrm{H}_{6} \mathrm{O}_{6}$ \\
\hline C & 175 & 3.2 & 270 & $\left(\mathrm{NH}_{4}\right)_{2} \mathrm{SO}_{4}+\mathrm{C}_{4} \mathrm{H}_{6} \mathrm{O}_{6}$ \\
\hline D & 175 & 3.2 & 240 & $\left(\mathrm{NH}_{4}\right)_{2} \mathrm{SO}_{4}+\mathrm{C}_{4} \mathrm{H}_{6} \mathrm{O}_{6}$ \\
\hline
\end{tabular}

$\mathrm{cm}^{3}$. Panels were made by adding $11 \%$ (face) and $8.5 \%$ (core) of urea-formaldehyde adhesive with $66 \%$ solid content, based on oven dry weight of particles. For the first series of panels (marked A), neat ammonium sulphate was used as hardener, while in other three series (marked B, C and D), the catalyst consisted of ammonium sulphate and tartaric acid. The hardener was added based on the solid content of the resin, $3 \%$ being added for the core layer and $0.2 \%$ for the face layer. In all series of particleboards, solid content of the catalyst was $20 \%$. In modified catalyst systems, $1 \%$ (based on solid content of resin) of ammonium sulphate was replaced with the same amount of solid tartaric acid, in accordance with the findings of our prior work (Španić et al., 2017). Paraffin emulsion solid content was $46 \%$ and was added to face layer ( $3 \%$ ) and core layer (4\%), respectively, based on resin weight.

All series of panels were pressed at $175^{\circ} \mathrm{C}$ and $3.2 \mathrm{~N} / \mathrm{mm}^{2}$ pressure, with pressing time and hardener used depending on the panel series (Table 1).

In each panel series, two boards were made and conditioned at $65 \%$ relative humidity and $20{ }^{\circ} \mathrm{C}$, before being sawn into test samples.

\subsection{Particleboard testing}

\subsection{Ispitivanje ploča iverica}

Prepared particleboards were tested in order to determine bending strength (MOR) and modulus of elasticity $(M O E)$ according to EN 310:1993 and internal bond (IB) according to EN 319:1993. Mechanical properties were determined using a Schenck Trebel universal testing machine (model UPM 20T). The dimensions of the test samples were determined according to EN 325:1993 using an INSIZE digital calliper (model 1137-150; $0.01 \mathrm{~mm}$ precision) and an INSIZE digital micrometre (model 3100-25; $0.001 \mathrm{~mm}$ precision). Board density was determined according to EN 323:1993 and their moisture content using a Memmert laboratory drying oven (model UF 110 plus) according to EN 322:1993. The weight of the test specimens was determined using a Sartorius digital laboratory balance (model TE 612-L; $0.01 \mathrm{~g}$ precision). Free formaldehyde content was determined according to EN 120:1992, using a Shimadzu UV-VIS spectrophotometer (model UV mini 1240). For each panel series and each property examined, 10 samples were prepared and tested. Free formaldehyde content was determined on one sample per board series.

Data obtained for each property examined was statistically analysed. The influence of partial replacement of ammonium sulphate hardener with tartaric acid on properties of particleboards was evaluated by analysis of variance (ANOVA). Tukey's HSD post hoc test was performed in order to identify which group (data for each property examined for each board series) was significantly different from other groups at $95 \%$ confidence level. Statistical analysis was performed using Statistica Ver.13.3 software (Tibco Software Inc.).

\section{RESULTS AND DISCUSSION} 3. REZULTATI I RASPRAVA

The results of mechanical properties of experimentally produced particleboards are given in Table 2 , namely their thickness, density and moisture content.

EN 312:2010 defines values of $0.35 \mathrm{~N} / \mathrm{mm}^{2}, 11$ $\mathrm{N} / \mathrm{mm}^{2}$ and $1600 \mathrm{~N} / \mathrm{mm}^{2}$ as minimum requirements for $I B, M O R$ and $M O E$, respectively, for Type $\mathrm{P} 2$ particleboards (boards for interior fitments, including furniture; for use in dry conditions). The same standard permits the value of $\leq 8 \mathrm{mg} / 100 \mathrm{~g}$ oven dry board, for the free formaldehyde content $\left(\mathrm{CH}_{2} \mathrm{O}\right)$. The results in Table 2 show that $1 \%$ replacement of ammonium sulphate with tartaric acid resulted in only minor changes in mechanical properties, if the board pressing time stayed the same (300 s). This is also the case regarding the free formaldehyde, whose content is $6.49 \mathrm{mg} / 100 \mathrm{~g}$ oven dry board for boards from series A and 6.54 $\mathrm{mg} / 100 \mathrm{~g}$ oven dry board for boards from series B (Figure 1). Both the boards from series A and B fulfil the minimum requirements, implying that tartaric acid has a positive effect on resin curing if the pressing time is not altered. However, this is not the case regarding the $I B$ of boards from series $\mathrm{C}$ and $\mathrm{D}$, which were pressed for 270 and 240 seconds, respectively. Although those values are lower, $M O R$ and $M O E$ values are still above the minimum required. The same is with the free formaldehyde content, which rises up to 7.6 $\mathrm{mg} / 100 \mathrm{~g}$ oven dry board for boards from series $\mathrm{C}$ and then drops back to $6.62 \mathrm{mg} / 100 \mathrm{~g}$ oven dry board for boards from series D (Figure 1).

Relative increase of MOR and MOE values accompanied by the decrease of IB values of boards hot pressed for 270 and 240 seconds is common. That is due to the fact that the shorter press time influences the relationship between board density and strength, thus leading to higher densification of outer layers, which highly contributes to the increase of MOR and MOE values and decrease of IB values (Moslemi, 1974). More precisely, due to short press time, the heat transfer to inner layers was insufficient, causing improper 
Table 2 Mechanical properties of experimentally produced particleboards

Tablica 2. Mehanička svojstva ploča iverica izrađenih za eksperiment

\begin{tabular}{|c|c|c|c|c|c|c|}
\hline $\begin{array}{l}\text { Property } \\
\text { Svojstvo }\end{array}$ & $\begin{array}{l}\text { Panel series } \\
\text { Serija ploča }\end{array}$ & $N$ & Mean \pm STD & Median & Min & Max \\
\hline \multirow{4}{*}{ Thickness / debljina, mm } & $\mathrm{A}$ & 10 & $15.16 \pm 0.15^{\mathrm{ab}}$ & 15.15 & 14.97 & 15.43 \\
\hline & $\mathrm{B}$ & 10 & $15.22 \pm 0.44^{\mathrm{ab}}$ & 15.38 & 14.56 & 15.73 \\
\hline & $\mathrm{C}$ & 10 & $15.61 \pm 0.26^{\mathrm{a}}$ & 15.42 & 15.31 & 15.96 \\
\hline & $\mathrm{D}$ & 10 & $15.15 \pm 0.40^{\mathrm{b}}$ & 14.97 & 14.71 & 15.91 \\
\hline \multirow{4}{*}{ Density / gustoća, $\mathrm{g} / \mathrm{cm}^{3}$} & $\mathrm{~A}$ & 10 & $0.75 \pm 0.04^{\mathrm{abc}}$ & 0.76 & 0.66 & 0.79 \\
\hline & $\mathrm{B}$ & 10 & $0.71 \pm 0.03^{\mathrm{c}}$ & 0.71 & 0.65 & 0.75 \\
\hline & $\mathrm{C}$ & 10 & $0.73 \pm 0.02^{\mathrm{a}}$ & 0.73 & 0.70 & 0.78 \\
\hline & $\mathrm{D}$ & 10 & $0.77 \pm 0.04^{\mathrm{ab}}$ & 0.78 & 0.67 & 0.82 \\
\hline \multirow{4}{*}{ Moisture content / sadržaj vode, \% } & $\mathrm{A}$ & 10 & $7.23 \pm 0.26^{\mathrm{a}}$ & 7.25 & 6.76 & 7.59 \\
\hline & $\mathrm{B}$ & 10 & $7.02 \pm 0.11^{\mathrm{a}}$ & 7.02 & 6.87 & 7.22 \\
\hline & $\mathrm{C}$ & 10 & $7.21 \pm 0.17^{\mathrm{a}}$ & 7.21 & 6.90 & 7.49 \\
\hline & $\mathrm{D}$ & 10 & $7.17 \pm 0.15^{\mathrm{a}}$ & 7.13 & 6.98 & 7.50 \\
\hline \multirow{4}{*}{$\begin{array}{l}\text { IB / vlačna čvrstoća okomito na površinu ploče, } \\
\mathrm{N} / \mathrm{mm}^{2}\end{array}$} & $\mathrm{~A}$ & 10 & $0.35 \pm 0.04^{\mathrm{a}}$ & 0.34 & 0.27 & 0.39 \\
\hline & $\mathrm{B}$ & 10 & $0.38 \pm 0.04^{\mathrm{a}}$ & 0.40 & 0.31 & 0.45 \\
\hline & $\mathrm{C}$ & 10 & $0.16 \pm 0.01^{\mathrm{b}}$ & 0.17 & 0.14 & 0.18 \\
\hline & $\mathrm{D}$ & 10 & $0.18 \pm 0.06^{\mathrm{b}}$ & 0.17 & 0.04 & 0.28 \\
\hline \multirow{4}{*}{ MOR / savojna čvrstoća, $\mathrm{N} / \mathrm{mm}^{2}$} & $\mathrm{~A}$ & 10 & $11.9 \pm 1.39^{\mathrm{a}}$ & 11.8 & 9.7 & 14.1 \\
\hline & $\mathrm{B}$ & 10 & $13.4 \pm 1.38^{\mathrm{ab}}$ & 13.2 & 11.6 & 15.9 \\
\hline & $\mathrm{C}$ & 10 & $13.9 \pm 1.83^{\mathrm{ab}}$ & 14.1 & 11.2 & 16.7 \\
\hline & $\mathrm{D}$ & 10 & $15.5 \pm 2.43^{b}$ & 15.3 & 11.7 & 19.0 \\
\hline \multirow{4}{*}{ MOE / modul elastičnosti savojne čvrstoće, $\mathrm{N} / \mathrm{mm}^{2}$} & $\mathrm{~A}$ & 10 & $2423.8 \pm 232.02^{\mathrm{a}}$ & \begin{tabular}{|l|}
2451.3 \\
\end{tabular} & 2081.0 & 2699.6 \\
\hline & $\mathrm{B}$ & 10 & $2503.7 \pm 256.97^{\mathrm{ab}}$ & 2535.6 & 2129.0 & 2892.2 \\
\hline & $\mathrm{C}$ & 10 & $2502.7 \pm 256.31^{\mathrm{ab}}$ & 2504.2 & 2092.7 & 2857.7 \\
\hline & $\mathrm{D}$ & 10 & $2841.0 \pm 345.07^{\mathrm{b}}$ & 2881.6 & 2594.2 & 3087.9 \\
\hline
\end{tabular}

* Means sharing the same superscript are not significantly different from each other (Tukey's HSD, $p<0.05$ )

* Srednje vrijednosti koje imaju istu slovnu oznaku međusobno se znatno ne razlikuju (Tukey's HSD, $p<0,05$ )

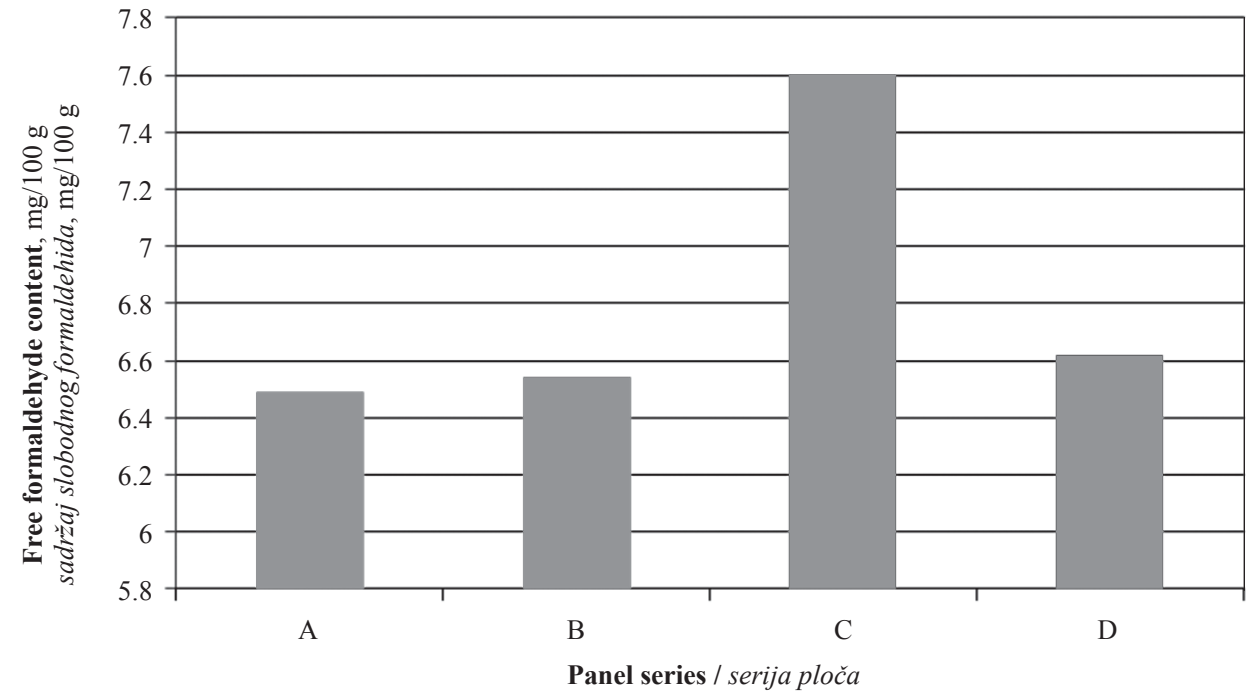

Figure 1 Free formaldehyde content of experimentally produced particleboards

Slika 1. Sadržaj slobodnog formaldehida ploča iverica izrađenih za eksperiment

resin polymerization in the core layers. The slight rise of free formaldehyde content in case of boards from series $\mathrm{C}$ and $\mathrm{D}$ is also an indication of improper resin polymerization in inner layers.

As already mentioned, the mechanical properties of boards from second series (B) are only slightly affected by the addition of tartaric acid, if compared with the results obtained for the boards made using neat ammonium sulphate (series A). Such results are likely due to the hardener $\mathrm{pKa}$ (acid dissociation change) that shifts to lower values as the temperature of wood particle mat increases. With the increase of temperature, tartaric acid $\mathrm{pKa}$ changed, thus lowering the $\mathrm{pH}$ value of the catalyst system, which resulted in somewhat faster resin curing time. Faster curing consequently helped the development of $I B, M O R$ and $M O E$ values (Wang and Winistorfer, 2003) in case of boards from the second series (B). 
The results given in Table 2 reveal that there are no significant differences in moisture content between individual panel series. Small differences in terms of board thickness could be associated with unevenness of metal sheets on which the wet mats were formed. The density drop from $0.75 \mathrm{~g} / \mathrm{cm}^{3}$ (series A) to $0.71 \mathrm{~g} /$ $\mathrm{cm}^{3}$ (series B) and its rise in series C and D (to $0.73 \mathrm{~g} /$ $\mathrm{cm}^{3}$ and $0.77 \mathrm{~g} / \mathrm{cm}^{3}$, respectively) could be an indication that, in case of the use of tartaric acid, the catalytic mechanism is independent of the free formaldehyde (Costa et al., 2014).

\section{CONCLUSION}

\section{ZAKLJUČAK}

This study showed that it is possible to use ammonium sulphate-based hardener partially replaced with tartaric acid for particleboard production. However, this is possible only if the panel press time is not too short (less than $300 \mathrm{~s}$ ), as results showed that the IB, MOR and MOE values, as well as free formaldehyde content, are under the influence of set press time. The results also imply that the hardener system and consequently the board properties are influenced by the addition of tartaric acid ( $\mathrm{pKa}$ values), leading to the conclusion that the particleboards could be produced using neat tartaric acid as hardener for UF resin. Still, this should be examined in further studies.

\section{REFERENCES}

\section{LITERATURA}

1. Aizat, A. G.; Paiman, B.; Lee, S. H.; Zaidon, A., 2019: Physico-mechanical properties and formaldehyde emission of Rubberwood particleboard made with UF resin admixed with ammonium and aluminium-based hardeners. Pertanika Journal of Science and Technology, 27 (1): 473-488.

2. Bekhta, P.; Sedliačik, J.; Saldan, R.; Novák, I., 2016: Effect of different hardeners for urea-formaldehyde resin on properties of birch plywood. Acta Facultatis Xylologiae Zvolen, 58 (2): 65-72. http://doi.org/10.17423/afx.2016.58.2.07.

3. Costa, N. A.; Pereira, J.; Ferra, J.; Cruz, P.; Martins, J.; Magalhães, F. D.; Mendes, A.; Carvalho, L. H., 2014: Formaldehyde emission in wood based panels: effect of curing reactions. International Wood Products Journal, 5 (3): $146-150$. http://doi.org/10.1179/2042645314Y.0000000070.

4. Čuk, N.; Kunaver, M.; Medved, S., 2011: Properties of particleboards made by using an adhesive with added liquified wood. Materials and Technology, 45 (3): 241245.

5. Liao, R.; Xu, J.; Umemura, K., 2016: Low density sugarcane bagasse particleboard bonded with citric acid and sucrose: Effect of board density and additive content. BioResources, 11 (1): 2174-2186.

6. Moslemi, A. A., 1974: Particleboard, Volume 2: Technology. Southern Illinois University Press, pp. 116-117.

7. Park, B.-D.; Kim, Y.-S.; Singh, A. P.; Lim, K. P., 2003: Reactivity, Chemical structure and molecular mobility of urea-formaldehyde adhesives synthesized under different conditions using FTIR and Solid-state ${ }^{13} \mathrm{C}$ CP/MAS
NMR spectroscopy. Journal of Applied Polymer Science, 88: 2677-2687. https://doi.org/10.1002/app.12115.

8. Pizzi, A., 2003: Urea-formaldehide adhesives. In: Pizzi, A.; Mittal, K. L. (eds.): Handbook of adhesive technology, second edition, revised and expanded. New York, Marcel Dekker Inc., pp. 635-652.

9. Španić, N.; Jambreković, V.; Radmanović, K.; Mihulja, G.; Kljak. J., 2017: Effect of tartaric acid addition to catalyst on curing behaviour of urea-formaldehyde resin. In: Župčić, I.; Živković, V.; Miklečić, J. (eds.): Proceedings of $28^{\text {th }}$ International conference on wood science and technology "Implementation of wood science in woodworking sector”. Zagreb, University of Zagreb Faculty of Forestry, pp. 51-57.

10. Umemura, K.; Sugihara, O.; Kawai, S., 2013: Investigation of a new natural adhesive composed of citric acid and sucrose for particleboard. Journal of Wood Science, 59: 203-208. https://doi.org/10.1007/s10086-013-1326-6.

11. Umemura, K.; Sugihara, O.; Kawai, S., 2015: Investigation of a new natural adhesive composed of citric acid and sucrose for particleboard II: effects of board density and pressing temperature. Journal of Wood Science, 61: 40-44. https://doi.org/10.1007/s10086-014-1437-8.

12. Uner, B.; Olgun, C., 2017: The effect of hardener on adhesive and fiberboard properties. Wood Research Slovakia, 62 (1): 27-36.

13. Wang, S.; Winistorfer, P. M., 2003: Monitoring resin cure during particleboard manufacture using dielectric system. Wood and Fiber Science, 35 (4): 532-539.

14. Widyorini, R.; Nugraha, P. A.; Rahman, M. Z. A.; Prayitno, T. A., 2016: Bonding ability of a new adhesive composed of citric acid-sucrose for particleboard. BioResources, 11 (2): 4526-4535.

15. Xing, C.; Zhang, S. Y.; Deng, J.; Wang, S., 2007: Ureaformaldehyde-resin gel time as affected by the $\mathrm{pH}$ value, solid content, and catalyst. Journal of Applied Polymer Science, 103: 1566-1569. https://doi.org/10.1002/app.25343.

16. *** EN 120: 1992, Wood based panels - Determination of formaldehyde content - Extraction method called the perforator method.

17. ${ }^{* * *}$ EN 310: 1993, Wood-based panels - Determination of modulus of elasticity in bending and of bending strength.

18. *** EN 312: 2010, Particleboards - Specifications.

19. *** EN 319: 1993, Particleboards and fibreboards - Determination of tensile strength perpendicular to the plane of the board.

20. ${ }^{* * *}$ EN 322: 1993, Wood based panels - Determination of moisture content.

21. *** EN 323: 1993, Wood-based panels - Determination of density.

22. *** EN 325: 2012, Wood based panels - Determination of dimension of test pieces.

\section{Corresponding address:}

Assist. prof. NIKOLA ŠPANIĆ, PhD

Institute of Material Technologies

University of Zagreb, Faculty of Forestry

Svetošimunska 25 , p. o. box 422

HR-10002 Zagreb, CROATIA

e-mail: nspanic@sumfak.hr 